\title{
International law and political philosophy: Uncovering new linkages
}

\section{Steven Ratner}

University of Michigan Law School

Correspondence

Steven Ratner, University of Michigan Law School, Ann Arbor, MI.

Email: sratner@umich.edu

\begin{abstract}
Despite a common agenda of normative analysis of the international order, philosophical work on international political morality and international law and legal scholarship have, until recently, worked at a distance from one another. The mutual suspicion can be traced to different aims and methodologies, including a divide between work on matters of deep structure, on the one hand, and practical institutional analysis and prescription, on the other. Yet international law is a key part of the normative practices of states, has a direct effect on state behavior, and, as a methodological matter, can contribute to good theorizing on matters of international ethics. Recently, philosophical work has demonstrated a greater engagement with the moral aspects of international law. One strand of scholarship has treated the rules of international law as a proper subject for philosophical inquiry. Another has used international legal rules to support moral arguments about aspects of the international order. Future dialogue and cooperation would benefit both fields, in particular on the challenges to global cooperation from nationalism and on strategies for allocating responsibilities among global actors for rectifying global harms.
\end{abstract}

\section{1 | INTRODUCTION}

Political philosophy's engagement with international political morality has significantly expanded in the last two decades. It has moved past what seemed to be its two long-standing staples-distributive justice and just war theory-to explore other aspects of the global political order, including title to territory, migration, climate change, 
and international trade. These new topics have offered opportunities for the field to take account of the current rules regulating the international system and those who appraise or theorize about them-international law and legal scholars. But philosophical work on international political morality varies on whether such encounters with law are an indeed an opportunity or a diversion. Indeed, what has been described as a "happy marriage" between international law and global justice (Valentini \& Torresi, 2011) more resembles the early phases of a rather undefined relationship.

This essay offers a critical account of the scope of interdisciplinarity across international law and political (and moral) philosophy on questions of international political morality (or global ethics, or global justice, though the latter term is sometimes limited to issues of distributive justice). Section 2 identifies some contrasting goals of philosophical and international legal theory on matters of global ethics and how these aims have perpetuated a distance between the disciplines, one that at best treats law through what I call the "International Law as Vessel" approach. Section 3 offers an alternative view of the relationship between the disciplines, making the case for certain kinds of interdisciplinarity. Section 4 offers a critical review of recent scholarship evincing interdisciplinarity by grouping it into two broad strategies, what I call "International Law as Target" and "International Law as Analytical Input." It shows how some recent work has demonstrated the advantages of such engagement. In Section 5, I propose a set of research agendas for philosophy on international political morality.

One caveat before continuing: While this essay will make ample reference to legal scholarship, it is designed primarily to address the state of play within political (and, to some extent, moral) philosophy. I do this for reasons of space and because, for the most part, international legal scholarship still tends to avoid contemporary political and moral philosophy, for reasons that remain frustratingly imbedded in the field (Ratner, 2013). Cohen's (1935) observation of eight decades ago that legal scholarship seeks refuge in concepts at the expense of analysis of the ethical determinants and consequences of legal decisions remains regrettably apt. Some scholars have taken legal work in an overtly interdisciplinary direction (see, e.g., Carmody, Garcia, \& Linarelli, 2012; Ratner, 2015), but most of the field remains at arms distance from contemporary international ethics. At the same time, ethical precepts and concepts (legitimacy, hegemony, exploitation, etc.) continue to play a strong part in theoretical work (see, e.g., the historical overview in Von Bernstorff \& Venzke, 2011), notably in scholarship within the orbit of critical legal and postcolonial approaches (Anghie, 2004; Chimni, 2018; Simpson, 2004; Sornarajah, 2015). In addition, a strain of international law scholarship engages directly with contemporary legal philosophy (see, e.g., Besson, 2009; Brunnée \& Toope, 2010).

\section{I TRACING PHILOSOPHICAL DISTANCE FROM INTERNATIONAL LAW}

Important methodological differences characterize philosophical approaches to international political morality and international law. ${ }^{1}$ First, philosophy will always be more abstract and foundational in some sense than law, with its focus on existing practice and institutions. A good philosophical argument about the underlying morality of the international order is grounded in principles and intuitions. A good legal argument about the normative structure of that order, on the other hand, is grounded in, and constrained by, precedent and practice. Lawyers must always be careful that their arguments are not too innovative in the sense of lacking a grounding in practice. Second, the two fields treat the messiness of real life quite differently. Philosophical arguments often rely on necessary and sufficient conditions, where one counterexample-even a fictional case involving Martians-may defeat an otherwise sound argument. The legal scholar, on the other hand, accepts that every law is in some way overinclusive or underinclusive and thus a sort of rule of thumb; the goal of prescriptive scholarship is to find a reasonably workable rule. And third, international lawyers and philosophers may have fundamentally different expectations of the role law should play in the international system, with the former more resigned to the role of power and politics-seeking to engage with those forces-and the latter seeking to blunt their influence.

These starting points help explain one fundamental distinction between much of the scholarship on global justice emanating from the two fields. Namely, philosophers are often concerned with the deep moral structure of the 
international order. They may ask why states have title to territory (see Moore, 2015; Stilz, 2011), the circumstances under which foreigners should be able to settle in a state (see Lefkowitz, 2015; Stilz, 2017), whether individuals or states have any duties of redistribution beyond their borders (compare,e.g., Cohen \& Sabel, 2006; Nagel, 2005), whether states should have open or closed borders (compare, Carens, 1987; Miller, 2005), or what should be the basic principles of justice for allocating responsibilities to combat climate change (see Caney, 2012). Even legal scholarship with little allegiance to the status quo doctrine tends to regard the search for a moral account for these core aspects of the international system as a bridge too far for legal theorizing. It is, put simply, too attenuated from the lawyer's-even most academic lawyers'-task, which is, at risk of some generalization, oriented toward analyzing and solving concrete problems through the institutions we have (even if reformed somewhat).

Yet even as many philosophers address such foundational questions, they differ in terms of their willingness to deploy institutional moral reasoning. In contrast to ideal theory-or at least one understanding of it (Valentini, 2012)that mode of reasoning takes into account, in various ways, existing international institutions (including the lack thereof) in justifying, criticizing, or theorizing the deep structure of the international political order. Such a view is defended on the ground that to ignore those institutions leads to principles "inconsistent with existing institutional arrangements whose abandonment would be morally prohibitive ... or because institutionalizing them would generate incentives that undermine the realization of other important principles" (Buchanan \& Golove, 2002, p. 870; see also Sutch, 2011). Thus, for instance, Buchanan's account of secession and humanitarian intervention seeks to find a philosophical justification and limitation for these practices (not the project of most legal scholarship) even as his account of each is grounded in realities and institutions of the international system, whether the lack of an international police force or the ideological and cultural diversity of states (Buchanan, 2004).

Because institutional moral reasoning is always considering-and accepting as somewhat fixed-the practices of states and other global actors, the resulting theories have a groundedness that opens up possibilities for their ideas to be the basis for actual reforms of the system. It is not that the theories or conclusions from such reasoning point toward preservation of the status quo. It is not even that they are easily feasible. But they are more translatable into new practices and new norms than theories that ignore those practices.

International law is, of course, a central institution to the international order, along with that most basic institution, the state. For the bulk of philosophical scholarship that seems uninterested in institutional reasoning, legal norms are easily set aside, for they would seem irrelevant to theorizing about ideal arrangements or about frameworks through which to evaluate morally various aspects of the global order. From this perspective, because much or most law emerges from a political process, it can neither ground nor undercut an ethical argument. Instead, international law becomes an instrument for delivering, institutionalizing, or enforcing a previously derived ethical position -or a second-best version of it. I would call this the "International Law as Vessel" approach.

One problem with the Vessel approach is that it appears to discount the moral significance of legal rules solely due to their (political and power-based) origins. Hurrell (2003) has offered one strong countervailing argument, pointing out that "the ethical claims of international law rest on the contention that it is the only set of globally institutionalized processes by which norms can be negotiated on the basis of dialogue and consent, rather than being simply imposed by the most powerful" (p. 277, emphasis in original). The inability of much political philosophy to address these ethical claims (which after all, are only claims, see, in contrast, Chimni, 2018) creates the distance we see today. ${ }^{2}$ A second problem is that those who deploy the Vessel approach fail to consider whether the legal vessel can institutionally handle their theory; the translation of moral principles into legal rules results in the philosophical equivalent of faux amis. For instance, some cosmopolitan scholars have suggested that the International Court of Justice serve as an arbiter for dealing with secessionist conflicts according to moral criteria of self-determination (Copp, 1998, p. 237; Altman \& Wellman, 2009, pp. 66-67), whereas international lawyers familiar with that court would point out its built-in conservativism in the face of uncertain norms and its tendency to avoid political controversy.

Yet we should hardly dismiss the Vessel approach, noninstitutional reasoning, and ideal theory more generally, for they can offer deep insights into the moral fiber of the world order. Indeed, such work is important for international law development itself. First, it can guide lawyers, academic and practicing, as they contemplate future 
lawmaking where the law does not yet regulate an important question, e.g., transborder migration. Second, it can inform decision makers, including international judges, on the interpretation of current rules, even as those decision makers may deny that they are taking ethical considerations into account but only applying norms of treaty interpretation. And third, it can provide a template for evaluating the moral adequacy of existing rules on an issue as part of a project of reform of those rules. It can do so by challenging fixed assumptions among international lawyers about the structure of the international order. Thus, for instance, an examination of the possibilities for regulating greenhouse gases from the perspective of corrective justice or distributive justice can help us evaluate the moral valence of the Paris climate agreement (see Caney, 2012), or theories questioning a state's sovereignty over its natural resources or control of its borders can help us assess the morality of the law of the sea or rules (or lack thereof) on refugees or migrants (see Carens, 1987). As Valentini (2018, pp. 670-673) has observed, feasibility-insensitivity is not a persuasive objection to ideal theory that seeks to be purely evaluative.

\section{3 | ENGAGEMENT WITH INTERNATIONAL LAW: JUSTIFICATIONS}

So why might philosophers-even those already committed to institutional moral reasoning-take the step of making international law relevant to their project of theorizing about the morality or justice of the international order?

First, international law is a key part of the normative universe of practices, institutions, and expectations that frame international-institutional moral reasoning. Norms of international law emerge from political, judicial, and other processes that, to varying degrees, global actors regard as legitimate and come with, again to varying degrees, mechanisms for promoting or enforcing compliance (see McDougal \& Reisman, 1981). Indeed, law is where many of the key claims about what a just world should look like are contested and ultimately resolved through rules. As Hurrell (2007) writes, "law can be viewed as a sociologically embedded transnational cultural practice in which claims and counterclaims can be articulated and debated and from which norms can emerge that can have at least some determinacy and argumentative purchase" (p. 313).

Second, and relatedly, because the rules of international law cover an enormous range of issues, and in many ways influence the way key actors like states behave regarding those issues, those rules are both a formalized instantiation, and in some cases even a causal factor, of the moral problems of global justice. All international legal regimes represent choices by states and other actors to regulate, or not regulate, international matters in ways that have winners and losers. As Nardin (2011) writes, "the global order that exists is substantially constituted by public international law" (p. 2071). To take one of countless examples, the international legal rule that gives states permanent sovereignty over their natural resources (good news for Qatar; bad news for Tonga) would seem central to accounts of global distributive justice, for it represents a decision by states to arrange economic wealth a certain way and is a barrier to some proposed redistribution schemes. Political philosophy has (from time to time) recognized its importance, from Barry's (1981) hasty dismissal of the norm as "without any rational foundation" (p. 36) to Armstrong's (2015) more serious challenge to it. A recent volume by Egede and Sutch (2013) presents a treatise on international law, embedded within which is a discussion of the justice implications of the rules from various theoretical perspectives.

Third, and more specifically methodological, international legal rules may assist all philosophers (even those not committed to institutional moral reasoning) in building up their theories. At the initial stage, law can assist in what McCrudden (2017, pp. 73-75) has called "concept formation." For instance, to understand the meaning of freedom of expression, we need to look at the forms of expression that humans attempt, which requires looking at those that governments have regulated in some way, as well as the responses of international courts like the European Court of Human Rights.

Once the concept is formed, legal norms and interpretations of them can serve a heuristic function, offering analogies that can help in the elaboration of basic principles of morality or justice. The derivation of norms by political 
actors, courts, expert bodies, and others helps identify the issues and dilemmas of the aspect of global justice under consideration, including the trade-offs and compromises that are and need to be made between moral values. The content of a legal norm can help us think about the identity of a moral duty holder and beneficiary, as well as the scope of a duty. It is thus a disservice to philosophical inquiry to ignore a long-running practice of grappling with moral complexity through legal rules, especially when those rules are accompanied by-as treaty drafters and interpreters often provide-a sophisticated justification for the route chosen (Cane, 2012, pp. 82-84). ${ }^{3}$ Indeed, for some subject areas, like human rights, the law can be seen as constitutive of morality (Besson, 2013).

Fourth, and also concerning methodology, international law can serve as a check on philosophical conceptions or theories of international political morality. The status of some norms as law could mean an acceptance by key global actors of a moral, and not merely a political, position. If the legal rules deviate significantly from the moral position of the philosopher, they would seem to represent a set of counterexamples that argue for revisiting one's theory and asking whether there is a good reason for the deviation. The philosopher should consider (a) why her position deviates from the rule of international law and the justification for the deviation; and (b) if she advocates a practical application of the theory, the systemic costs to changing the extant rule to one consistent with the theory.

\section{I ENGAGEMENT WITH INTERNATIONAL LAW: TWO MODALITIES}

These arguments for interdisciplinarity seem to have resonated in recent years in the form of two distinct philosophical encounters with international law, though each has antecedents in older works. Each stands in sharp contrast to the "International Law as Vessel" approach discussed above. ${ }^{4}$

\subsection{International law as target}

The first strand takes international law's rules as a direct target of inquiry. It is, in a sense, institutional moral reasoning where the subject of the reasoning is the institution of international law. Much of this field asks whether the various distinctions that the law makes in regulating an issue, in particular the scope of legal duties and of duty holders, reflect morally significant differences. Just war theory established a key foothold in this camp with Walzer's (2015) Just and Unjust Wars, whose examination centers on the "war convention," by which he means the laws of war and the practices under them (p. 44). The revisionist just war theory of McMahan (2009) and his adherents, however, deviates significantly from this orientation, defending a new morality about warfare from principles about individual self-defense. The theory sees legal rules as a fundamental mismatch with this deep theory of the morality of war, though it has acknowledged the advantages of the rules as guides for soldiers in combat. A recent assessment of the morality of the law of war with a deeper appreciation for legal rules is found in the work of Haque (2017), who is both a lawyer and a philosopher. While endorsing some ideas of the revisionists, he treats the treaties and practices of states as deserving a sustained (and more sympathetic) moral inquiry and as providing moral guidance to soldiers as well. This defense, critique, and interpretation of the laws of war to reflect notions of just war seems far more likely to be treated seriously by some of those who conduct wars than the revisionist dismissal of the law of war as fatally flawed-though the revisionists may not see the point of their work as creating real-world effects.

Philosophy's long-standing scrutiny of the laws of war as well as its attention to the morality of the criminal law may jointly explain the keen interest of philosophers in international criminal law (ICL). That field includes criminalization of violations of the laws of war (war crimes) and also other core crimes like genocide, crimes against humanity, and aggression. The philosophy of ICL has been dominated by efforts to find a moral justification for states' decisions to make some acts international crimes. These crimes can be punished by international tribunals (like the International Criminal Court) or by individual states through the legal construct of universal jurisdiction, including over the objection of the state where the atrocities took place. Most theories, from initial attempts by Luban (2004), May (2005), and Altman and Wellman (2004) to more recent work, tend to focus on the gravity of the crimes as a basis for what some 
of them call an international jurisdiction that encompasses both trials by international tribunals and by all states (Lee, 2010, p. 18; Chehtman, 2010). Song's (2015) account of universal jurisdiction rejects the attempt to match international crimes with gravity but sees it as an attempt by states to address gaps in the ability of states to enforce criminal law. The debates among just war theorists between the mainstream and revisionist views also have ramifications for what violations should be criminalized (see, e.g., Chehtman, 2018; Fabre, 2016).

Yet these attempts to find a moral account of international crimes still miss a key question. While theorizing about the legitimacy of interest in the crimes by states other than where they were committed (and, by extension, by international courts), they ignore the consequences that can arise from prosecution by other states or by international courts of individuals for the crimes. When justice becomes personal, and not just about state duties, the metaphorical gloves can come off. The operation of universal jurisdiction and international criminal tribunals can create tensions between states, interfere with the implementation of peace agreements ending civil wars, or otherwise make transitions from authoritarian rule more complex. This concern about how an institution operates in practice is almost intuitive to international lawyers; a full moral account or justification of international criminalization requires addressing these potential consequences as well (for one attempt, see Ratner, 2015, pp. 279-290).

Like just war theory and ICL, the philosophy of human rights makes international law a central target of inquiry. Though certain influential accounts work from first principles without applying those principles to existing law (see, e.g., Shue, 1996), others analyze the legal rules. But the range of approaches to such engagement is wide. Griffin's concept of human rights is derived independently of international law, indeed, without recourse to institutional moral reasoning. When he assesses the law, his goal is merely to determine whether the rights it codifies match up with the morally justified human rights as he has theorized them (Griffin, 2009). Buchanan has persuasively criticized this "mirroring view" for failing to appreciate the function and practices that human rights serve in the international system. He considers it more important to offer a moral account of the system of legalized human rights. (Buchanan, 2013, pp. 53-81). Cristina Lafont has offered a wholly different defense of human rights, one responding to claims that they are a tool of powerful states, arguing that states' obligations under international human rights law actually protect weak states against economic agreements that she regards as draconian. As a result, the international protection of human rights, including through the Responsibility to Protect, does not undermine the sovereignty of weak states, but rather only demands that they meet certain international standards that have been accepted by all (Lafont, 2016).

The direct engagement approach also extends to areas of international economic law. Scholarship on international economic rules tends to be oriented toward criticizing them for undermining distributive justice, even as most distributive justice scholarship remains the foundational and noninstitutional work described earlier (e.g., responses to Rawls' Law of Peoples and related questions about the ambit of distributive justice at the global level.). Thus, Pogge's work, from his defense of the globalization of the difference principle (Pogge, 1989) to his work on international rules on intellectual property, is part of the distributive justice discourse (see Pogge, 2005, 2012). In this tradition, Risse's (2012) human rights-oriented theory of global justice provides a lens for his criticism of the rules of the World Trade Organization. James' (2012) theory of structural equity produces three principles regarding justifiable gains from trade, which he then deploys to criticize current rules on international trade, labor, and intellectual property. More recently, he has relied on these principles to condemn international rules on investment that protect investors of one state from arbitrary or harmful action by the state where they invest (James, 2017).

Yet these works on distributive justice reveal a significant limitation in some philosophical accounts of international law, one identified by international lawyers themselves. First, international lawyers have pointed out how the criticisms of economic rules measure them against a standard that is impossible to achieve in practice (Howse \& Teitel, 2010, p. 438). Second, they have noted that some of the philosophical criticisms of the rules assume causation between them and the distributive injustice they identify-or replacement of the rules and greater distributive justice-when in fact the patterns of causation are much more complex (Dunoff, 2012 and Trachtman, 2012). For instance, in the field of international investment law, the impact of treaties requiring states to afford certain protections to foreign investors on a state's regulatory freedom or on economic inequality within or among states has 
not been measured quantitatively (see Ratner, 2018). And third, others note that calls for reform of particular international rules to address distributive injustice often fail to consider whether the rule is the right institutional site for carrying out distributive justice, in terms of the feasibility of the reform, the effectiveness of the reform in improving the status quo, and the possible downsides to reforming the current rule (Trachtman, 2012, pp. 275-277; Tan, 2014, p. 205).

A more nuanced and convincing critique of the legal rules on international economic matters is Leif Wenar's study of the resource curse, which takes aim at the international law rule that gives the government with effective control over a state the right to sell its resources. He convincingly demonstrates how the rule empowers corrupt rulers to rob their countries of their wealth. Yet rather than simply calling for the rule's abolition-a move we might expect from philosophers facing an immoral rule-he accepts the institutional constraints on eliminating it and develops an alternative way of preventing money from getting to corrupt leaders that rely on policies of purchasing states (Wenar, 2016). Nonetheless, Wenar downplays possible advantages of the international law rule regarding a government's capacity to control state resources,e.g., that a questioning of that authority could cause other states to recognize competing clusters of power within a state, fostering intrastate and even interstate violence.

Among the most promising avenues for interdisciplinarity are works that move beyond the comfort zones of rules on war, crimes, and human rights and of distributive justice. Several works focus on key international law norms on statehood. Stilz (2015) has offered a new moral defense of the norm of decolonization, arguing that decolonization can only be justified in terms of achieving the goal of group self-determination in the face of alien rule. And Armstrong (2015) has focused on the related international law norm of permanent sovereignty over natural resourcesthe state's claim to the resources regardless of its form of government-finding that it does not serve the purposes that its defenders have advanced (regardless of its implications for distributive justice).

Lastly, a large body of literature within political and legal philosophy has taken international law writ large-particularly in its contrast to domestic law-as a subject of inquiry. Rather than inquiring into the morality or justice of rules governing specific subject areas, it asks whether and why states must, as a moral matter, observe international law-including when international law might be in tension with the state's duties to its own people and what makes for a legitimate set of international legal rules (for a review of scholarship, see Pavel \& Lefkowitz, 2018). Among recent contributions, David Lefkowitz has argued that states have a moral obligation to obey international law based on considerations of fairness (Lefkowitz, 2011). And Carmen Pavel has offered an account of how international institutions, including international law, can constrain and empower states to fulfill their moral obligations to their citizens (Pavel, 2015). These theories are generally sympathetic to international law and seem in part a response to skepticism of states' compliance with it among some conservative U.S. legal commentators (see, e.g., Posner, 2003).

\subsection{International law as analytical input}

The second track of engagement does not treat the rules as objects of appraisal but as inputs, in a broad sense, into a good moral theory. This approach, though it has some analytic variations, is also not new. Goodin's (1988) pioneering article justifying a state's special duties to its own nationals on utilitarian grounds pointed out situations where, under international law, a state's duties to foreigners are actually greater than its duties to its citizens to rebut the strong nationalist claim that states should always owe greater duties to their own citizens than to foreigners. Terry Nardin's theory of interstate justice is grounded squarely in a traditional positivist notion of international law-international law is, indeed not merely one input but the basis for just interstate relations-as are aspects of Rawls' Law of Peoples (Nardin, 1998; Rawls, 1999). As noted, Buchanan (2004) has emphasized international rules as part of the practices and expectations of states that shape and constrain theories of self-determination, the use of force, and human rights.

More recent work shows a welcome continuation and perhaps intensification of this invocation of legal norms. Andreas Follesdal has joined the debate on the existence of duties of global distributive justice by arguing that the norms of international law and institutions create a global basic structure that is regulated by principles of distributive 
justice. Follesdal rebuts a number of claimed necessary conditions for a basic structure, but he also argues that the web of international agreements meets some of those conditions as well,e.g., through their direct impact on individuals and their evolution in part independently of states (Follesdal, 2011). In addition, Goodin has used international law principles of jurisdiction to show how states can extend the reach of their laws to those beyond their borders. This extension of state authority and its recognition by international law is essential to his argument that all persons subjected to such laws, wherever located, ought to have a say in the content of those laws (Goodin, 2016). Finally, Miller (2014, pp. 117-118) has recently invoked the flexibility of international law's rules on the borders of dissolving states as an argument for a more flexible approach to determining title to disputed territory.

International Law as Analytical Input is thus distinct from International Law as Vessel, International Law as Target, and international law scholarship itself. Unlike the Vessel approach, it sees the decision of states to put something into a legal rule as informing our understanding of what is just or unjust about the world. Unlike the Target approach, it is not focused on a moral justification for existing rules. In the pieces mentioned above, the authors set aside that question and take the rules as fixtures on the international scene that will serve an instrumental purpose in their argument. I would argue that their treatment of the rules constitutes an implicit endorsement of them, especially as the very same scholars feel free to criticize other rules that they find lack moral justification. And unlike international law scholarship, International Law as Analytical Input, for all its receptivity to international law, is still asking questions that lawyers would find too abstract.

\section{I IS GREATER INTERDISCIPLINARITY POSSIBLE?}

If readers are persuaded by the reasons offered above for integrating international law and international political morality, a number of paths toward dialogue and collaboration seem promising. Indeed, one of the fascinating aspects of observing philosophical scholarship from the outside is how the same author may choose, in different works, to follow the Vessel approach, the Target approach, or the Analytical Input approach (though many seem stuck in the first).

As for the Target approach, a number of regimes of international law are overdue for philosophical investigation. These regimes can be identified as those that are (a) important to the functioning of the global order, and yet (b) so morally opaque, or at least under-analyzed, that they deserve attention from political philosophers. A few of the most obvious targets are the rules of state immunity, which prohibit courts in one state from asserting jurisdiction over other states, their officials, and their diplomats; international economic law, in particular investment, which reflects assumptions about the free market, corporations, and state power; rules on refugees and migration that remain mostly hostile to those fleeing war, violence, and poverty; the rules that give states jurisdiction over some conduct beyond their borders (not merely universal jurisdiction); and the powers and limitations of international tribunals, whether in the area of human rights, trade, investment, or land and sea border disputes. Legal scholarship on these topics is vast, but each raises important questions about the moral grounding of state power and the extent to which law serves the ends of individuals or of states.

But the ground is equally fertile for the second form of interdisciplinarity, which calls for a greater embrace of institutional moral reasoning on topics already in a sense on the radar screen of political philosophers irrespective of the legal issues associated with them. Two are worthy of mention. One is the challenge of nationalism and illiberalism in various corners of the world. On the one hand, cosmopolitan philosophical perspectives have tended to be quite dismissive of the legitimacy of non-democracies in the international order, a position that may seem validated by the threats of nationalist or illiberal regimes to their own populations and to global order. On the other hand, in the real world, most states, including one of the two most politically and economically influential in the world, are not liberal democracies, so the focus on democracy becomes a diversion to theorizing that connects to real-world problems. Because international legal regimes are based on cooperation among many different types of domestic governmental systems, its practices offer analogies or strategies for a moral account of diversity across states and an approach to addressing the threats from some regimes. Whatever one might think of Rawls' (1999) theory demanding 
toleration of (some) non-liberal states, international law shows that the achievement of certain morally desirable ends requires cooperation between liberal and illiberal states. It also shows that those states can find areas of agreement of benefit to both individuals (e.g., on certain human rights issues like women's rights, nondiscrimination, slavery, and torture) and the planet (e.g., on climate change and species conservation).

A related issue is the allocation of responsibilities among states, international institutions, corporations, individuals, and other actors for carrying out (a or the) just solution to a global problem. Allocation cuts across issues such as climate change, settlement of refugees and migrants, severe poverty, cybersecurity and privacy, and termination of atrocities beyond our borders. Philosophical and legal scholarships have mostly worked on parallel tracks in developing theories of responsibility (Pierik, 2015). They share the insight that responsibility can be both backward-looking in the sense of causation and forward-looking in the sense of a determination of who should act to improve the status quo. Philosophers have made important recent contributions on the nature of institutional responsibility (Erskine, 2014) as well as identifying the moral grounds for different global actors to assume responsibility for rectifying global problems (Barry \& Øverland, 2016). Lawyers look much more pragmatically at which actors are in the best position to solve the problem in consequentialist terms, taking into account feasibility as well. Thus, for instance, international law has developed the concept of "common but differentiated responsibilities" to address a number of environmental issues, from ozone depletion to climate change. The idea is that, while all states must undertake burdens, certain states by virtue of their wealth or size have additional responsibilities to solve undertake action (Sands, 2003, pp. 285-289). International law has many ideas to offer international political morality on finding an "all-things-considered justified" moral response to the problems of global cooperation.

It is hoped that the opportunities for better work on international political morality through exposure to international law will appeal to more political philosophers. At this stage, the relationship is in its early stages, with the exception of a few areas like just war theory and human rights. Like all interdisciplinary explorations, the learning curve will be steep, or at a minimum require collaboration from scholars across fields. But the payoff for both understanding the moral valence of the international order and the means for changing it remain significant-namely, a more institutionally sensitive, practically informed, and (for those who care) policy-guiding set of principles of international political morality.

\section{ENDNOTES}

${ }^{1}$ This paragraph benefitted from comments of the participants in the Workshop on Interdisciplinary Approaches to Global Justice held in Ann Arbor on May 18-19, 2017 and notably remarks of David Luban.

${ }^{2}$ As noted in Section 1, legal philosophy has begun to reckon with these questions.

${ }^{3}$ I also appreciate this insight from Charles Beitz.

${ }^{4}$ This account leaves aside encounters exclusively focused on the philosophy of law.

\section{ORCID}

Steven Ratner (10 https://orcid.org/0000-0002-3269-2801

\section{WORKS CITED}

Altman, A., \& Wellman, C. H. (2004). A defense of international criminal law. Ethics, 115, 35-67. https://doi.org/10.1086/ 422895

Altman, A., \& Wellman, C. H. (2009). A liberal theory of international justice. Oxford: Oxford University Press. https://doi.org/ 10.1093/acprof:oso/9780199564415.001.0001

Anghie, A. (2004). Imperialism, sovereignty and the making of international law. Cambridge: Cambridge University Press.

Armstrong, C. (2015). Against 'permanent sovereignty' over natural resources. Politics, Philosophy \& Economics, 14, 129-151. https://doi.org/10.1177/1470594X14523080

Barry, B. (1981). Do countries have moral obligations? The case of world poverty. The Tanner Lectures on Human Values, 2, 25-44. 
Barry, C., \& Øverland, G. (2016). Responding to global poverty: Harm, responsibility, and agency. Cambridge: Cambridge University Press. https://doi.org/10.1017/CBO9781139381758

Besson, S. (2009). The authority of international law-Lifting the state veil. Sydney Law Review, 31, 343-380.

Besson, S. (2013). The law in human rights theory. Zeitschrift für Menschenrechte, 2013(1), 120-150.

Brunnée, J., \& Toope, S. J. (2010). Legitimacy and legality in international law: An interactional account. Cambridge: Cambridge University Press. https://doi.org/10.1017/CBO9780511781261

Buchanan, A. (2004). Justice, legitimacy, and self-determination. Oxford: Oxford University Press.

Buchanan, A. (2013). The heart of human rights. Oxford: Oxford University Press. https://doi.org/10.1093/acprof:oso/ 9780199325382.001.0001

Buchanan, A., \& Golove, D. (2002). Philosophy of international law. In J. Coleman, \& S. Shapiro (Eds.), The Oxford handbook of jurisprudence and philosophy of law (pp. 868-934). Oxford: Oxford University Press.

Cane, P. (2012). Morality, law and conflicting reasons for action. Cambridge Law Journal, 71, 59-85. https://doi.org/10.1017/ S0008197312000207

Caney, S. (2012). Just emissions. Philosophy \& Public Affairs, 40, 255-300. https://doi.org/10.1111/papa.12005

Carens, J. H. (1987). Aliens and citizens: The case for open borders. The Review of Politics, 49, 251-273. https://doi.org/ $10.1017 /$ S0034670500033817

Carmody, C., Garcia, F. J., \& Linarelli, J. (Eds.) (2012). Global justice and international economic law: Opportunities and prospects. New York, NY: Cambridge University Press.

Chehtman, A. (2010). The philosophical foundations of extraterritorial punishment. Oxford: Oxford University Press. https:// doi.org/10.1093/acprof:oso/9780199603404.001.0001

Chehtman, A. (2018). Revisionist just war theory and the concept of war crimes. Leiden Journal of International Law, 31, 171-194. https://doi.org/10.1017/S0922156517000498

Chimni, B. S. (2018). Customary international law: A third world perspective. American Journal of International Law, 112, 1-46. https://doi.org/10.1017/ajil.2018.12

Cohen, F. S. (1935). Transcendental nonsense and the functional approach. Columbia Law Review, 35, 809-849. https://doi. org/10.2307/1116300

Cohen, J., \& Sabel, C. (2006). Extra rempublicam nulla justitia? Philosophy \& Public Affairs, 34, 147-175. https://doi.org/ 10.1111/j.1088-4963.2006.00060.x

Copp, D. (1998). International law and morality in the theory of secession. The Journal of Ethics, 2, 219-245. https://doi.org/ 10.1023/A:1009732228806

Dunoff, J. L. (2012). The political geography of distributive justice. In C. Carmody, F. J. Garcia, \& J. Linarelli (Eds.), Global justice and international economic law: Opportunities and prospects (pp. 153-184). New York: Cambridge University Press.

Egede, E., \& Sutch, P. (2013). The politics of international law and international justice. Edinburgh: Edinburgh University Press.

Erskine, T. (2014). Coalitions of the willing and responsibilities to protect: Informal associations, enhanced capacities, and shared moral burdens. Ethics \& International Affairs, 28, 115-145. https://doi.org/10.1017/S0892679414000094

Fabre, C. (2016). Cosmopolitan peace. Oxford: Oxford University Press. https://doi.org/10.1093/acprof:oso/ 9780198786245.001 .0001

Follesdal, A. (2011). The distributive justice of a global basic structure: A category mistake? Politics, Philosophy \& Economics, 10, 46-65. https://doi.org/10.1177/1470594X10396302

Goodin, R. E. (1988). What is so special about our fellow countrymen? Ethics, 98, 663-686. https://doi.org/10.1086/292998

Goodin, R. E. (2016). Enfranchising all subjected, worldwide. International Theory, 8, 365-389. https://doi.org/10.1017/ S1752971916000105

Griffin, J. (2009). On human rights. Oxford: Oxford University Press.

Haque, A. A. (2017). Law and morality at war. Oxford: Oxford University Press. https://doi.org/10.1093/acprof:oso/ 9780199687398.001.0001

Howse, R., \& Teitel, R. (2010). Global justice, poverty, and the international economic order. In S. Besson, \& J. Tasioulas (Eds.), The philosophy of international law (pp. 437-449). Oxford: Oxford University Press.

Hurrell, A. (2003). International law and the making and unmaking of boundaries. In A. Buchanan, \& M. Moore (Eds.), States, nations, and borders: The ethics of making boundaries (pages). Cambridge: Cambridge University Press.

Hurrell, A. (2007). On global order: Power, values, and the constitution of international society. Oxford: Oxford University Press. James, A. (2012). Fairness in practice: A social contract for a global economy. New York, NY: Oxford University Press. 
James, A. (2017). Investor rights as nonsense-On stilts. In L. Herzog (Ed.), Just financial markets? Finance in a just society (pp. 205-228). Oxford: Oxford University Press.

Lafont, C. (2016). Sovereignty and the international protection of human rights. Journal of Political Philosophy, 24, 427-445. https://doi.org/10.1111/jopp.12086

Lee, W. (2010). International crimes and universal jurisdiction. In L. May, \& Z. Hoskins (Eds.), International criminal law and philosophy (pp. 15-38). New York: Cambridge University Press.

Lefkowitz, D. (2011). The principle of fairness and states' duty to obey international law. Canadian Journal of Law and Jurisprudence, 24, 327-346. https://doi.org/10.1017/S0841820900005191

Lefkowitz, D. (2015). Autonomy, residence, and return. Critical Review of International Social and Political Philosophy, 18, 529-546. https://doi.org/10.1080/13698230.2014.927117

Luban, D. (2004). A theory of crimes against humanity. Yale Journal of International Law, 29, 85-167.

May, L. (2005). Crimes against humanity: A normative account. Cambridge: Cambridge University Press.

McCrudden, C. (2017). What does it mean to compare, and what should it mean? In S. Besson, L. H. Urscheller, \& S. Jubé (Eds.), Comparing comparative law (pp. 61-84). Geneva: Schulthess éditions romandes.

McDougal, M. S., \& Reisman, W. M. (1981). The prescribing function in the world constitutive process: How international law is made. In M. S. McDougal, \& W. M. Reisman (Eds.), International law essays: A supplement to international law in contemporary perspective (pp. 355-380). Mineola, NY: Foundation Press.

McMahan, J. (2009). Killing in war. Oxford: Clarendon Press.

Miller, D. (2005). Immigration: The case for limits. In A. I. Cohn, \& C. H. Wellman (Eds.), Contemporary debates in applied ethics (pp. 193-206). Malden, MA: Blackwell Publishing.

Miller, D. (2014). Debatable lands. International Theory, 6, 104-121. https://doi.org/10.1017/S1752971914000050

Moore, M. (2015). A political theory of territory. New York: Oxford University Press.

Nagel, T. (2005). The problem of global justice. Philosophy \& Public Affairs, 33, 113-147. https://doi.org/10.1111/j.10884963.2005.00027.x

Nardin, T. (1998). Legal positivism as a theory of international society. In D. R. Mapel, \& T. Nardin (Eds.), International society: Diverse ethical perspectives (pp. 17-35). Princeton, NJ: Princeton University Press.

Nardin, T. (2011). Justice and authority in the global order. Review of International Studies, 37, 2059-2072. https://doi.org/ $10.1017 /$ S0260210511000313

Pavel, C. E. (2015). Divided sovereignty: International institutions and the limits of state authority. New York: Oxford University Press.

Pavel, C. E., \& Lefkowitz, D. (2018). Skeptical challenges to international law. Philosophy Compass, 13(8). https://doi.org/ 10.1111/phc3.12511

Pierik, R. (2015). Shared responsibility in international law: A normative-philosophical analysis. In A. Nollkaemper, \& D. Jacobs (Eds.), Distribution of responsibilities in international law (pp. 36-61). Cambridge: Cambridge University Press.

Pogge, T. (2005). Recognized and violated by international law: The human rights of the global poor. Leiden Journal of International Law, 18, 717-745.

Pogge, T. (2012). The health impact fund: Enhancing justice and efficiency in global health. Journal of Human Development and Capabilities, 13, 537-559. https://doi.org/10.1080/19452829.2012.703172

Pogge, T. W. (1989). Realizing Rawls. Ithaca, NY: Cornell University Press.

Posner, E. A. (2003). Do states have a moral obligation to obey international law? Stanford Law Review, 55, $1901-1919$.

Ratner, S. (2013). Ethics and international law: Integrating the global justice project(s). International Theory, 5, 1-34. https:// doi.org/10.1017/S1752971913000109

Ratner, S. R. (2015). The thin justice of international law: A moral reckoning of the law of nations. Oxford: Oxford University Press.

Ratner, S. R. (2018). Global investment rules as a site for moral inquiry. Journal of Political Philosophy, 27. (forthcoming 2019)

Rawls, J. (1999). The law of the peoples: With "the idea of public reason revisited". Cambridge, MA: Harvard University Press.

Risse, M. (2012). On global justice. Princeton, NJ: Princeton University Press.

Sands, P. (2003). Principles of international environmental law (2nd ed.). Cambridge: Cambridge University Press.

Shue, H. (1996). Basic rights: Subsistence, affluence, and U.S. foreign policy (2nd ed.). Princeton, NJ: Princeton University Press.

Simpson, G. (2004). Great powers and outlaw states: Unequal sovereigns in the international legal order. Cambridge: Cambridge University Press. 
Song, J. (2015). Pirates and torturers: Universal jurisdiction as enforcement gap-filling. Journal of Political Philosophy, 23, 471-490. https://doi.org/10.1111/jopp.12044

Sornarajah, M. (2015). Resistance and change in the international law on foreign investment. Cambridge: Cambridge University Press.

Stilz, A. (2011). Nations, states, and territory. Ethics, 121, 572-601. https://doi.org/10.1086/658937

Stilz, A. (2015). Decolonization and self-determination. Social Philosophy and Policy, 32(1), 1-24.

Stilz, A. (2017). Settlement, expulsion, and return. Politics, Philosophy \& Economics, 16, 351-374. https://doi.org/10.1177/ $1470594 \times 17729133$

Sutch, P. (2011). Human rights and the use of force: Assertive liberalism and just war. European Journal of Political Theory, 11 , 172-190.

Tan, K.-C. (2014). Sufficiency, equality and the consequences of global coercion. Law, Ethics and Philosophy, 2, 190-209.

Trachtman, J. P. (2012). Doing justice: The economics and politics of international distributive justice. In C. Carmody, F. J. Garcia, \& J. Linarelli (Eds.), Global justice and international economic law: Opportunities and prospects (pp. 273-286). New York: Cambridge University Press.

Valentini, L. (2012). Ideal vs. non-ideal theory: A conceptual map. Philosophy Compass, 7, 654-664. https://doi.org/10.1111/ j.1747-9991.2012.00500.x

Valentini, L. (2018). The case for ideal theory. In C. Brown, \& R. Eckersley (Eds.), The Oxford handbook of international political theory (pp. 664-673). Oxford: Oxford University Press.

Valentini, L., \& Torresi, T. (2011). Introduction-International law and global justice: A happy marriage. Review of International Studies, 37, 2035-2041.

Von Bernstorff, J., \& Venzke, I. (2011). Ethos, ethics, and morality in international relations. In Max Planck Encyclopedia of Public International Law. Retrieved from http://opil.ouplaw.com/view/10.1093/law:epil/9780199231690/law9780199231690-e936?rskey=V1cULR\&result=1\&prd=EPIL.

Walzer, M. (2015). Just and unjust wars: A moral argument with historical illustrations (5th ed.). New York, NY: Basic Books. Wenar, L. (2016). Blood oil: Tyrants, violence, and the rules that run the world. Oxford: Oxford University Press.

\section{AUTHOR BIOGRAPHY}

Steven Ratner is the Bruno Simma Collegiate Professor of Law at the University of Michigan Law School. His research addresses a range of public international law issues, including the regulation of foreign investment, individual and corporate accountability for human rights violations, normative orders concerning armed conflict, and the intersection of ethics and international law. He has served on two expert panels of the UN Secretary-General addressing post-conflict justice in Cambodia and in Sri Lanka and is a member of the U.S. Department of State Advisory Committee on International Law. His most recent book is The Thin Justice of International Law: A Moral Reckoning of the Law of Nations, issued by the Oxford University Press in 2015.

How to cite this article: Ratner S. International law and political philosophy: Uncovering new linkages. Philosophy Compass. 2019;14:e12564. https://doi.org/10.1111/phc3.12564 